\title{
Effect of Aloysia citrodora Essential Oil on Biochemicals, Antioxidant Characteristics, and Shelf Life of Strawberry Fruit during Storage
}

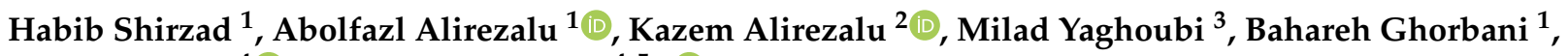 \\ Mirian Pateiro ${ }^{4}$ (D) and José $M$. Lorenzo ${ }^{4,5, * \mathbb{D}}$ \\ 1 Department of Horticultural Sciences, Faculty of Agriculture, Urmia University, \\ Urmia P.O. Box 165-5715944931, Iran; h.shirzad@urmia.ac.ir (H.S.); a.alirezalu@urmia.ac.ir (A.A.); \\ ghorbani.bahareh@ymail.com (B.G.) \\ 2 Department of Food Science and Technology, Ahar Faculty of Agriculture and Natural Resources, \\ University of Tabriz, Tabriz 51666, Iran; kazem.alirezalu@tabrizu.ac.ir \\ 3 Department of Food Science and Technology, Faculty of Agriculture, University of Tabriz, Tabriz 51666, Iran; \\ m.yaghoubi97@ms.tabrizu.ac.ir \\ 4 Centro Tecnológico de la Carne de Galicia, Parque Tecnológico de Galicia, rúa Galicia No. 4, \\ San Cibrao das Viñas, 32900 Ourense, Spain; mirianpateiro@ceteca.net \\ 5 Área de Tecnología de los Alimentos, Facultad de Ciencias de Ourense, Universidad de Vigo, \\ 32004 Ourense, Spain \\ * Correspondence: jmlorenzo@ceteca.net
}

check for updates

Citation: Shirzad, H.; Alirezalu, A.; Alirezalu, K.; Yaghoubi, M.; Ghorbani, B.; Pateiro, M.; Lorenzo, J.M. Effect of Aloysia citrodora Essential Oil on Biochemicals, Antioxidant Characteristics, and Shelf Life of Strawberry Fruit during Storage. Metabolites 2021, 11, 256. https:/ / doi.org/10.3390/metabo11050256

Academic Editor: Peter Meikle

Received: 22 March 2021

Accepted: 19 April 2021

Published: 21 April 2021

Publisher's Note: MDPI stays neutral with regard to jurisdictional claims in published maps and institutional affiliations.

Copyright: (C) 2021 by the authors Licensee MDPI, Basel, Switzerland. This article is an open access article distributed under the terms and conditions of the Creative Commons Attribution (CC BY) license (https:/ / creativecommons.org/licenses/by/ $4.0 /)$.

\begin{abstract}
Strawberry fruits are highly susceptible to cold burning, resulting in low storage periods at low temperatures. Plant extracts or essential oils (EOs) can potentially be used as preservatives in fruits throughout the refrigerated period. In the present study, the biochemicals, antioxidant characteristics, and shelf life of treated strawberries with Aloysia citrodora essential oil (ACEOs) were evaluated during keeping time. The treatments were produced as follows: T1, control; T2, 250 ppm ACEOs; T3, 500 ppm ACEOs; and T4, 750 ppm ACEOs. Total soluble solids (TSS), weight loss, titratable acidity (TA), antioxidant activity (DPPH assay), total phenolic (TPC), flavonoid and anthocyanin contents (TFC), and enzymes activity (peroxidase and ascorbate peroxidase) were evaluated during the refrigerated period $\left(5{ }^{\circ} \mathrm{C}\right.$ with relative humidity of $85-90 \%$ for 20 days). The results revealed that weight loss and TA were reduced in all treatments during storage, being that the rates were lower in samples treated with ACEOs. TPC, TFC, TSS, antioxidant, and enzymes activity were higher in treated fruits than control.
\end{abstract}

Keywords: Aloysia citrodora; strawberry; essential oil; antioxidant; shelf life

\section{Introduction}

Strawberry (Fragaria $\times$ ananassa Duch, from Rosaceae family) is one of the most perishable fruits, which could be related to its high respiration, high water content, high metabolic activity, and susceptibility to microbial contamination. The quality of the fruit depends on the appearance, texture, aroma, taste, and nutritional values [1]. The strawberry is a rich source of ascorbic acid and anthocyanin, which not only give antioxidant properties to the strawberries, but also many health benefits, such as enhancing the body's immune system and reducing the risk of developing cancers [2,3].

The applications of artificial antimicrobials for increasing the fruit's shelf life are linked to toxicity effects, which has led to the search for healthier options. Therefore, the recent use of natural sources in fruits to control quality properties is known as one of the more efficient techniques [4,5]. In this regard, the application of essential oils (EOs) could lead to delaying fruit spoilage, maintaining the quality, and increasing the shelf life [6]. EOs have potential antifungal properties and are used as disinfectants, which would allow 
them to reduce early fruit deterioration and increase the fruit's post-harvest life [7]. In recent decades, many efforts have been made to increase the shelf life of the strawberry fruit and maintain its nutritional values [8]. Maintenance of foods using methods such as controlled atmosphere [9] and the use of natural compounds [10] have been reported. One of the suitable and operational methods for increasing shelf life and maintaining quality attributes is the application of edible coatings based on natural essential oils [11]. Chitosan coating enriched with lemon $\mathrm{EO}$ has been used to protect strawberries from gray mold [12]. In addition, the combination of thyme $\mathrm{EO}$ with edible coatings is an effective way to minimize the deterioration of fruit by controlling microbiological growth, and also directly leads to improving the fruit quality [13].

The Aloysia citrodora plant contains neral, 1,8-cineole, geraniol, limonene, tannin, phenolic acids, flavonoids, and alkaloids [14]. Many studies have been conducted on the phytochemicals and antioxidant properties of the Aloysia citrodora plant [15], which have confirmed its antioxidant properties [16]. In addition, the protection effect of the Aloysia citrodora plant has been proven [15]. The activities of catalase, glutathione peroxidase, and glutathione reductase enzymes in damaged cells have increased. Post-harvest damages of strawberry fruits, at cold storage, including fungal pathogens, water and biochemical loss, and softening resulted in a low shelf life of the strawberries (approximately 5 days). Therefore, the aim of the present work was to extend the shelf life of strawberries by using non-chemical post-harvest treatment. Particularly, the impacts of different levels of A. citrodora EOs throughout post-harvest cold storage on enzymatic activities, antioxidant capacity, and biochemical constituents in strawberries were assessed. The obtained results can provide natural and Gras resources for the food industry and post-harvest technology.

\section{Results and Discussion}

\subsection{Weight Loss}

The weight loss and water loss of fruit samples were both decreased throughout the keeping period, which may have been caused by evaporation. Based on obtained results, the samples treated with ACEOs showed a lower weight loss compared to the control. The samples treated with $750 \mathrm{ppm}$ ACEOs displayed the lowest percentage of weight loss compared to other treatments during the storage period (Figure 1). The results also indicated that treated samples with 750 ppm ACEOs displayed 50\% lower weight loss than those observed in control samples. This demonstrated that several post-harvest treatments such as chemical treatments [17], coating [18], and physical treatments [19] can reduce cold burning, thus reducing susceptibility to fungal and bacterial contamination.

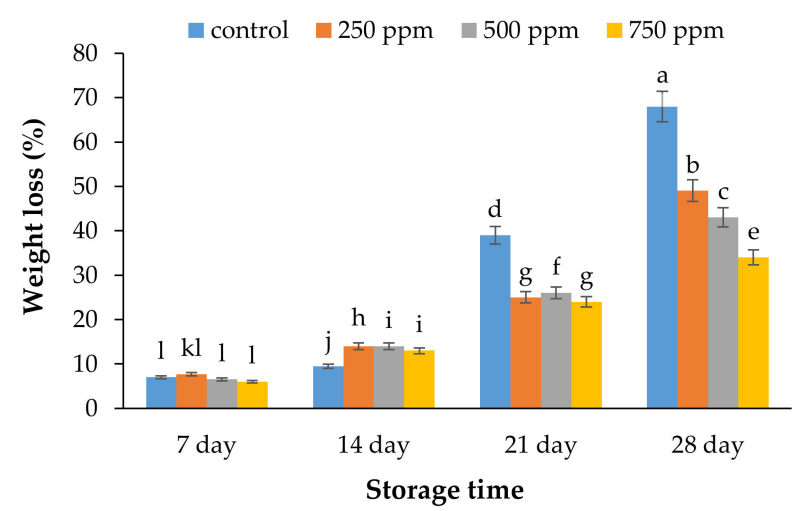

Figure 1. Effect of ACEOs on the weight loss of strawberries during storage. Different letters indicate a significant difference $(p<0.01)$ between samples.

\subsection{Chemical Characteristics (Titratable Acidity and Total Soluble Solid)}

The results indicated that the TSS of control samples was lower than that of treated samples. Treated samples with $750 \mathrm{ppm}$ ACEOs had the highest dissolved solids content (Figure 2a). The amount of total carbohydrates was one of the most important factors 
in increasing the texture resistance of the fruit to stress, since conversion of starch into reducing sugars is a positive factor during stress. In addition, the fact that most organic acids are secondary metabolites that are formed as a result of a citric acid cycle, and are used during respiration because acidity increases with raising storage duration, confirms the results of the present study [20].

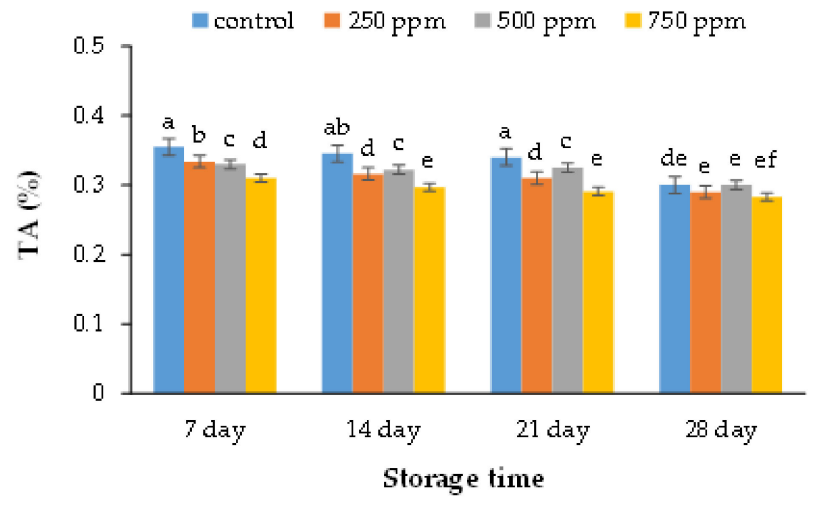

(a)

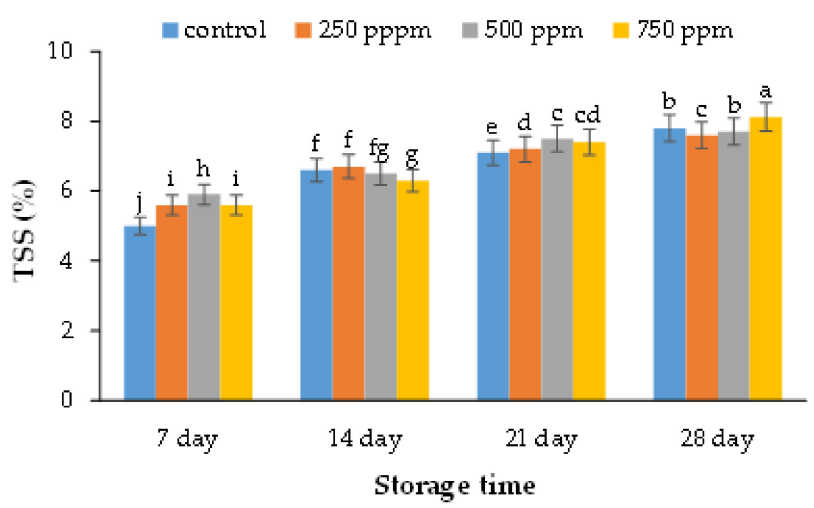

(b)

Figure 2. Effect of ACEOs on the quality attributes TA (a) and TSS (b) of strawberries during storage. Different letters indicate a significant difference $(p<0.01)$ between samples.

Based on the obtained results, the control and treated samples with $750 \mathrm{ppm}$ ACEOs displayed the highest and lowest amount of TA, respectively (Figure $2 \mathrm{~b}$ ). The results revealed that the acid levels decreased in strawberry samples during the keeping period (particularly in low-temperature rooms), which may be attributed to acids breaking down into sugar throughout fruit respiration. On the other hand, enzymatic activities in fruit juice during the keeping period could be another reason for acidity reduction [21]. The organic acids consumed during respiration would support normal activities in fruit samples during storage time [22]. However, enzymatic reactions and respiration could be decreased by edible coatings [23]. Edible coatings were capable of creating a modified atmosphere around fruit samples and maintaining $\mathrm{CO}_{2}$ at higher amounts; therefore, EOs decreased the consumption of organic acids by reduction in respiration and production of ethylene [24].

The organic acids accumulation during the fruit ripening process played an important role in the carboxylic acid glycolysis cycle. The fluctuation in organic acids led to changes in acidity; however, increasing in one parameter led to decreasing in other one. Therefore, acidity in orange fruits was affected by various types of acids such as citric acid, malic acid, benzoic acid, tartaric acid, and oxalic acid [25]. Carbohydrates and organic acids in the fruit could potentially influence taste and flavor attributes. However, most of the organic acids were secondary metabolites of the citric acid cycle during fruit breathing; therefore, acidity increased throughout the storage period. These results are paralleled with previous results reported by Burdurlu et al. [26] and Shao et al. [27].

There is limited research on the organoleptic attributes of treated fruits with EOs. Neri et al. [28] showed that added (E)-hex-2-enal in nectarine and peach fruits as "green" (leafy) resulted in off-odors. However, off-odors declined throughout ripening, and nothing was perceived after ripening. In contrast, applied carvacrol or citral had no bad effects on the odor of nectarine and peach fruits. According to results reported by Aloui et al. [12], there were no off-odors or off-flavors in dates treated with citrus EOs. Serrano et al. [29] also evaluated the effects of thymol and eugenol on cherries and reported no organoleptic effects. Prasad and Stadelbacher [30] indicated that acetaldehyde in low concentration (1\%) did not reveal any off-flavor in strawberries, while a higher concentration of acetaldehyde $(4 \%)$ resulted in off-flavor.

According to reviewed articles, a wide range EOs do not leave bad effects on intact fruit odors and flavors at low levels, particularly when stored fruits finish their ripening 
process. However, there is variation among cultivars and fruit species, and each commodity has to be tested separately. For instance, Neri et al. [28] indicated that pome fruits were less sensitive against (E)-hex-2-enal injury compared to stone fruits, which may be attributed to higher absorption of (E)-hex-2-enal by pome fruits.

\subsection{Antioxidant Activity by DPPH Assay}

The outcomes of DPPH values indicated that antioxidant capacity of the samples was at its highest content at the end of the keeping time. The antioxidant properties of the samples displayed that 250 ppm AFEOs had the highest antioxidant activity compared to other treatments (Figure 3 ). The results indicated that the use of $A$. citrodora EOs in edible coatings, by decreasing the rates of oxidation reactions, could reduce the damage of reactive oxygen species. However, by increasing the concentration of EOs, the antioxidant activities of coating increased. Antioxidant activity was increased throughout keeping time in all samples, and the rate of this activity was higher in treated samples compared to the control. The antioxidant activities of fruit samples are potentially related to the content of flavonoids and phenols, which are presented highly in plant extracts and EOs [31]. In recent decades, the application of medicinal plant extracts and EOs has become known as a new and safe method to improve the quality stability and the shelf life of the samples [32,33]. According to Alirezalu et al. [34] and Shameh et al. [35], the findings of the antioxidant capacity of strawberries were related to phenolic compounds such as tannin, and TFC. Synowiec et al. [36] evaluated the effects of Ocimum basilicum extract on apples. The authors demonstrated that the antioxidant capacity of the samples was effectively increased throughout the keeping period. According to results reported by Sellamuthu et al. [37], the herbal extracts and EOs improved berry fruits' antioxidant capacity, quality stability, and shelf life.

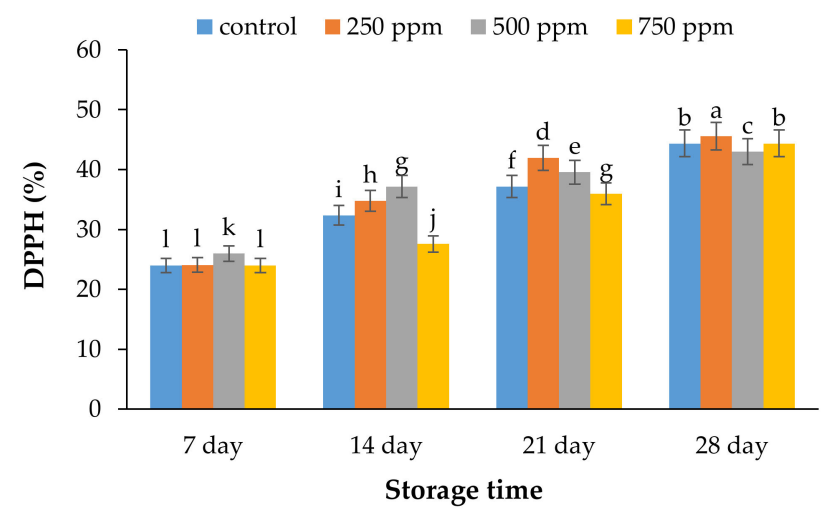

Figure 3. Effect of ACEOs on the antioxidant activity of strawberries during storage. Different letters indicate a significant difference $(p<0.01)$ between samples.

\subsection{Total Phenolic Content (TPC)}

Fruit samples treated with 250 and 500 ppm ACEOs displayed the highest amounts of total phenolic compounds (Figure 4a). In contrast, higher TPC of treated samples with 500 ppm ACEOs as compared to 750 ppm ACEOs at days 14 and 21 might be attributed to the toxic impacts of higher EO levels on the cells, resulting in breakdown of the cellular structure, which could be related to aging and the enhanced activity of the polyphenol oxidase enzyme [38]. Plant tissues are a rich source of phenolic compounds, including flavonoids, tannins, hydroxycinnamic esters, and lignin [39]. The higher amounts of phenolic compounds in plant sources might be the main reason for the higher total phenolic compounds in treated samples with ACEOs compared to the control. As expected, samples treated with 750 ppm ACEOs had the highest phenol levels. Phenolic compounds in plant materials are highly susceptible to environmental and biological stresses [40]. The phenolic compounds play an important role in reducing or inhibiting lipid autoxidation, eliminating free oxygen radicals, or decomposing peroxides [41]. The results of this work indicated that 
treated samples with higher concentrations of ACEOs displayed higher amounts of TPC, which paralleled results reported by Yang et al. [42] and Wang and Xu [43] on blueberry and strawberry, respectively.

Phenolic compounds, as secondary metabolites of plants, have potential antimicrobial properties [44]. Stimulation of phenolic compounds in treated strawberries by ACEOs may be the main reason for low decay occurrence in the samples. According to previous results, plants' EOs are a new and safe method to control post-harvest pathogens of berry fruits. On the other hand, these compounds improve the quality attributes and shelf life of berries [37]. The results of the present work indicated that treated strawberries with ACEOs displayed significantly higher amounts of TPC compared to the control at day 28.

\subsection{Total Flavonoid Content (TFC)}

The results of total flavonoid content are displayed in Figure $4 \mathrm{~b}$. The results indicated that samples treated with $750 \mathrm{ppm}$ ACEOs had significantly higher TFC compared to other groups. Previous results may be attributed to the fact that plant extracts or EOs are a rich source of phenolic and flavonoid compounds. In this way, higher amounts of flavonoids (as potential antioxidant ingredients) in treated samples could increase the shelf life of strawberries, compared to the control.

Total phenolic content, particularly flavonoids (TFC) with potential antioxidant activities, are extremely beneficial to consumers. These components can deactivate free radicals in plants, which may be caused by hydroxyl groups [45]. Ripening of the fruits throughout the storage could be the main reason for the increase in flavonoids in the present work [21] The control samples displayed a lower content of flavonoids than the coated samples. The types of fruits, as well as composition index, could affect the amount of flavonoids [45].

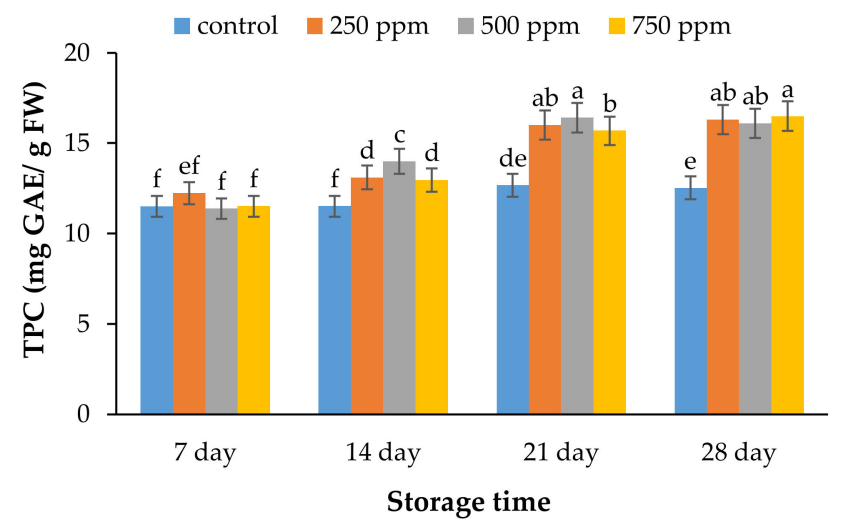

(a)

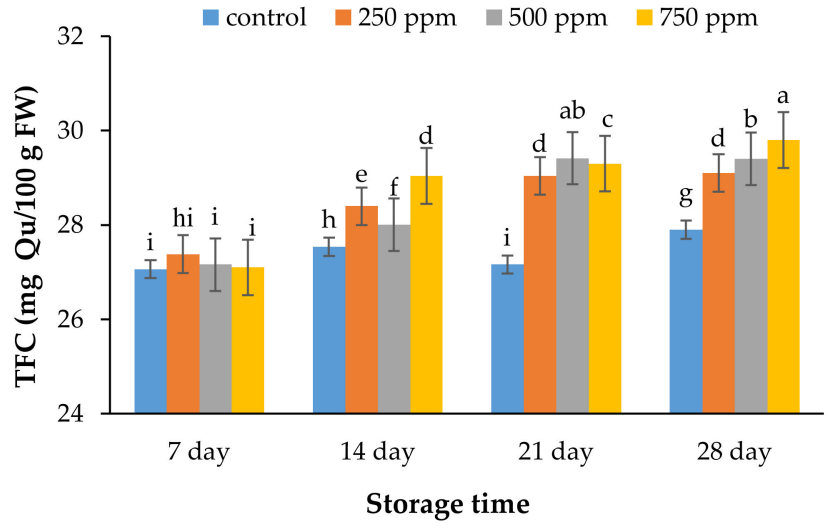

(b)

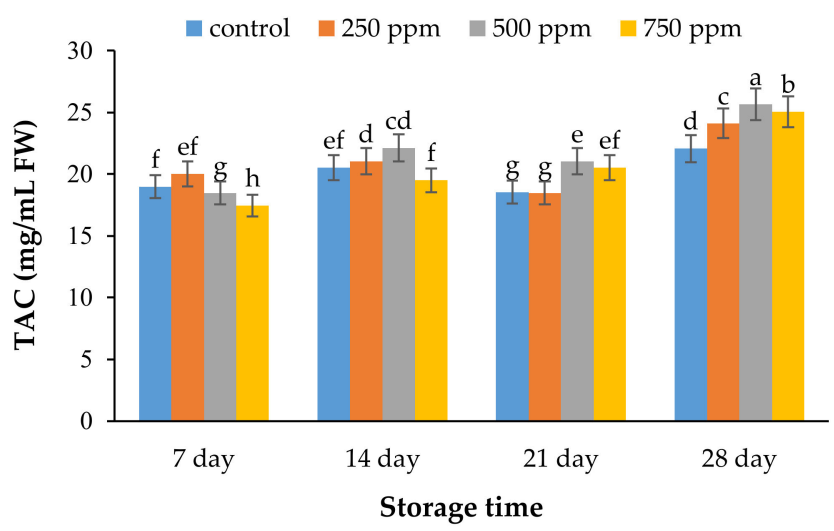

(c)

Figure 4. Effect of ACEOs on (a) total phenolic content, (b) total flavonoid content, and (c) total anthocyanin content of the strawberries during storage. Different letters indicate a significant difference $(p<0.01)$ between samples. 
The content and types of flavonoids are one of the most important ingredients in plants for controlling stress tolerance [46], and these are increased under stress [20]. Therefore, flavonoids play an important role in control of plant stress types due to their antioxidant properties and their specific structure. In fact, strawberries treated with $750 \mathrm{ppm}$ ACEOs showed significantly higher amounts of TFC compared to other groups at the end of the storage period.

\subsection{Total Anthocyanin Content (TAC)}

The results of the total anthocyanin content are illustrated in Figure 4c. The color of the strawberry fruit is derived from anthocyanin content. In this regard, da Silva et al. [47] found that more than 25 anthocyanins have been reported in different cultivars of strawberries, with pelargonidin 3-O-glucoside, pelargonidin 3-O-rutinoside, and cyanidin 3-O-glucoside being the main components. TAC of all samples decreased gradually during storage, which may be caused by oxidation reactions.

\subsection{Peroxidase Enzyme Activity}

The results of the peroxidase enzyme activity of strawberries are presented in Figure $5 \mathrm{a}$. The results indicated that treated strawberries with $500 \mathrm{ppm}$ ACEOs had the highest levels of peroxidase enzyme activity. Peroxidases play a vital role in metabolic steps of the cell, such as auxin catabolism, lignin synthesis, and suberin [48]. Peroxidases in the presence of phenolic compounds and ascorbic acid can act as an effective inhibitor against apoplast and vacuole [49]. Therefore, the peroxidase with potential antioxidant properties could extend the shelf life of products [3].

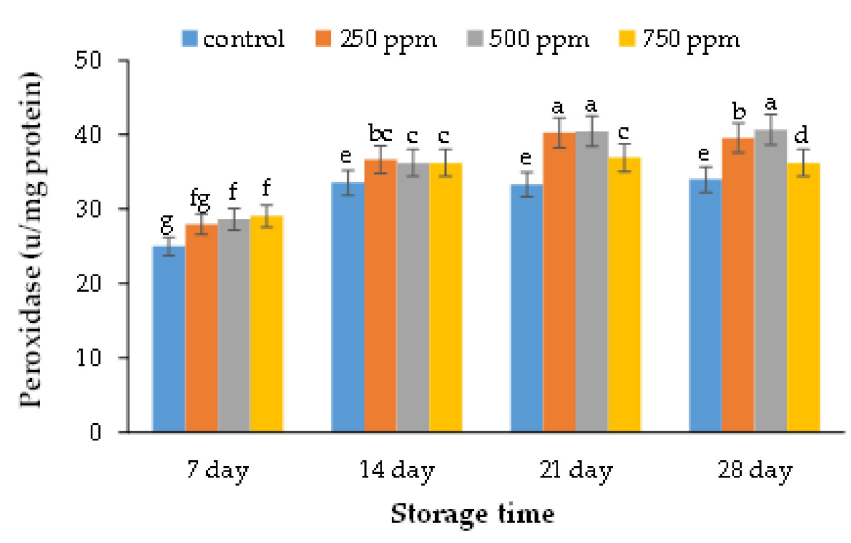

(a)

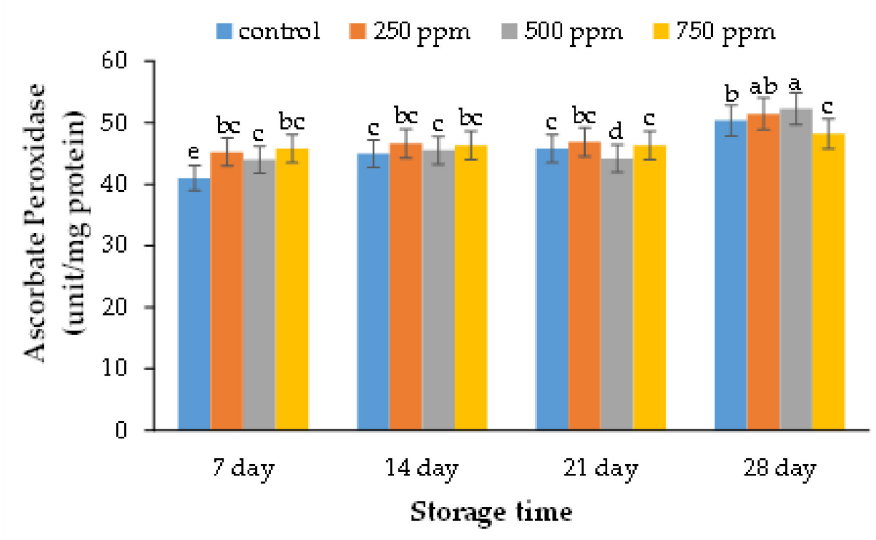

(b)

Figure 5. Effect of ACEOs on the (a) peroxidase and (b) ascorbate peroxidase enzyme activity of strawberries during storage. Different letters indicate a significant difference $(p<0.01)$ between samples.

\subsection{Ascorbate Peroxidase Enzyme Activity}

The results of the ascorbate peroxidase enzyme activity of strawberries are illustrated in Figure $5 b$. The results showed that the highest level of peroxidase enzyme was observed in strawberries treated with $500 \mathrm{ppm}$ ACEOs. Ascorbate peroxidase enzymes activity could prevent plants from being damaged by activated oxygen species when exposed to severe stress. Afshar Mohammadian et al. [50] proved that the cold resistance of two olive cultivars could be related to the total protein content, which was higher in sensitive olive cultivars. In addition, during cold stress the defensive enzymes activity against oxidative stress was increased; while after the cold stress, the protein storage of the plant increased to return to the normal state [51]. 


\section{Materials and Methods}

\subsection{Fruits}

The test cultivar utilized in the present work was Albion (Fragaria $\times$ ananassa Duch. cv. Albion). The strawberries were taken at commercial maturity stage from a commercial greenhouse in Urmia, West Azerbaijan province, Iran. Sampling was carried out early in the morning. The fruit was selected for the similarity of size, maturity, and color, and the damaged and unshaped fruit samples were removed. The samples were then transferred in a fridge of $4 \pm 1{ }^{\circ} \mathrm{C}$ to the Department of Horticulture Science of Faculty of Agriculture of Urmia University (Urmia, Iran).

\subsection{Preparation of ACEOs and Treatments}

In order to extract Aloysia citrodora essential oil, dried leaves were used for water distillation using a Clevenger apparatus. After preparing different concentrations of ACEOs $(0,250,500$, and $750 \mathrm{ppm})$, and due to their lipophilic properties and insolubility in distilled water, samples were mixed with Tween $80(0.5 \%, v / v)$. Then, the samples $(60 \mathrm{~g})$ were dipped in the ACEOs for 5 minutes. The fruits were put into sterilized packaging. Finally, all samples were transferred to a refrigerator $\left(5^{\circ} \mathrm{C}\right.$, with relative humidity of $85-90 \%$ ) and analyzed at 1, 7, 14, 21, and 28 days of keeping time.

\subsection{Weight Loss}

For determination of the samples' weight loss, 15 samples were selected and weighed. The percentage of weight loss was calculated as follows [52]:

$$
\text { Weight Loss }(\%)=\frac{\text { Primary weight }- \text { secondary weight }}{\text { Primary weight }} \times 100
$$

\subsection{Chemical Characteristics (Titratable Acidity and Total Soluble Solid)}

Total acidity was calculated by the titration method using sodium hydroxide $(0.1 \mathrm{~N})$ in terms of citric acid. In other words, it was titrated with soda solution $(0.1 \mathrm{~N})$ to reach $\mathrm{pH}$ 8.3. After applying, the value of the used soda was introduced in the following formula, and the acidity was calculated based on $\mathrm{g}$ of citric acid in $2 \mathrm{~L}$ of fruit extract and then converted to a percent [53]:

$$
\mathrm{TA}=\frac{100 \times \mathrm{M} \times \mathrm{N} \times \mathrm{V}}{\mathrm{S} \times \mathrm{n}}
$$

where TA = acidity value based on $\mathrm{g}$ of citric acid in $2 \mathrm{~L}$ sample extract, $\mathrm{M}=$ molecular weight of the dominant acid, $\mathrm{n}=$ dominant acid capacity, $\mathrm{V}=$ volume of the used soda, $\mathrm{S}=$ amount of the extract used, and $\mathrm{N}=$ normality of the used soda.

A manual refractometer (ATAGO, Tokyo, Japan) was utilized for measurement of total soluble solid (TSS) after calibration with distilled water [54].

\subsection{Antioxidant Activity by DPPH}

Firstly, the juice of the samples was extracted by pressure [55] and centrifuged at $11,000 \times g$ at $4^{\circ} \mathrm{C}$ for $15 \mathrm{~min}$. The obtained juice was utilized for evaluation of DPPH, TPC, and TFC.

The total antioxidant properties of the samples were evaluated by 2,2-diphenyl-1picrylhydrazyl-hydrate (DPPH) method. For this purpose, $2000 \mu \mathrm{L}$ of the DPPH (preprepared) solution was poured into the sterilized test tubes. Then, a specific amount of the fruit extract of each of the samples was added, and the resulting solution was shaken at room temperature and placed in the dark for $30 \mathrm{~min}$. The value of the absorbance of the resulting solution was read by a spectrophotometer at a wavelength of $517 \mathrm{~nm}$. The above method was also used to prepare the control, but instead of the extract, $80 \%$ methanol was used and calculated according to the following formula [56]: 


$$
\mathrm{RSA}=\frac{(\text { Abs control }) \mathrm{t}=30 \mathrm{~min}-(\text { Abs sample }) \mathrm{t}=30 \mathrm{~min}}{(\text { Abs control }) \mathrm{t}=30 \mathrm{~min}} \times 100
$$

\subsection{Total Phenolic Content (TPC)}

TPC was determined using Folin-Ciocalteu reagent according to the method of Alirezalu et al. [4]. A total of $30 \mu \mathrm{L}$ concentrated extract was poured into the test tube, and $90 \mu \mathrm{L}$ distilled water was added. Then, $600 \mu \mathrm{L}$ of $10 \%$ Folin was added, and after $10 \mathrm{~min}$, $480 \mu \mathrm{L}$ of $7.5 \%$ sodium carbonate was added, and after placing it for $30 \mathrm{~min}$ in the dark at room temperature, a spectrophotometer (UV-1800, Shimatzu Corporation, Kyoto, Japan) was used to read the absorbance at $760 \mathrm{~nm}$. Gallic acid was used as a standard. The total phenol content of extracts was expressed as $\mathrm{mg}$ of gallic acid equivalent (GAE)/g FW of the sample.

\subsection{Total Flavonoid Content (TFC)}

To measure the total flavonoid content, $500 \mu \mathrm{L}$ of the prepared extract was poured into the test tube, and $150 \mu \mathrm{L}$ of $5 \%$ sodium nitrite was added. After $5 \mathrm{~min}, 300 \mu \mathrm{L}$ of $10 \%$ aluminum chloride was added, and again, after $5-10 \mathrm{~min}, 1000 \mu \mathrm{L}$ of $1 \% \mathrm{NaOH}$ was mixed into the resulting solution and was brought to a volume of $5 \mathrm{~mL}$ with the deionized water. The absorbance of the resulting mixture was read at $380 \mathrm{~nm}$, compared to the control. Quercetin was used to draw the standard curve. The total flavonoid content of the total extracts was expressed as $\mathrm{mg}$ of quercetin equivalent $(\mathrm{Qu}) / 100 \mathrm{~g}$ FW of the sample [57].

\subsection{Total Anthocyanin Content (TAC)}

The $\mathrm{pH}$ difference method was used to measure the total anthocyanin content. For this purpose, the fruit juice was centrifuged at $11,000 \times \mathrm{g}$ for $15 \mathrm{~min}$ at $4{ }^{\circ} \mathrm{C}$, and then, $100 \mu \mathrm{L}$ of a supernatant was used. Two buffers were prepared with $\mathrm{pH} 1$ and 4 . Then, $2.5 \mathrm{~mL}$ of buffer 1 was poured into the test tube. Afterward, $100 \mu \mathrm{L}$ of the extract was added to the solution poured into the test tube, and the absorbance at two wavelengths of $700 \mathrm{~nm}$ and $530 \mathrm{~nm}$ was read. Next, $2.5 \mathrm{~mL}$ of buffer 2 ( $\mathrm{pH} 4.5$ ) was poured into another test tube and $100 \mu \mathrm{L}$ of the extract was added, and the absorbance at two wavelengths of $700 \mathrm{~nm}$ and $530 \mathrm{~nm}$ was read. Finally, the following formula was used to be calculated the total absorbance of each of the extracts [35]:

$$
\mathrm{A}=(\mathrm{A} 530-\mathrm{A} 700) \mathrm{pH}=1-(\mathrm{A} 530-\mathrm{A} 700) \mathrm{pH}=4.5
$$

Total anthocyanin content was calculated according to the following formula:

$$
\mathrm{TAC}=\frac{\mathrm{A} \times \mathrm{MW} \times \mathrm{V} \times \mathrm{DF} \times 100}{\varepsilon \times 100}
$$

where $\mathrm{A}=$ absorbance, $\mathrm{MW}=$ molecular weight, $\mathrm{DF}=$ dilution factor, and $\varepsilon=$ molar absorbance. The results were expressed as $\mathrm{mg}$ of cyanidin-3-O-glucoside $/ \mathrm{mL}$ of fruit juice.

\subsection{Peroxidase Enzyme Activity}

Peroxidase enzyme activity of the samples was evaluated according to Mohammadi et al. [58]. Briefly, $2 \mathrm{~mL}$ of tris buffer $(100 \mu \mathrm{M}, \mathrm{pH}=7.5), 300 \mu \mathrm{L}$ of oxygen peroxide of $5 \mu \mathrm{m}$, and $200 \mu \mathrm{L}$ guaiacol $(10 \mu \mathrm{M})$ were mixed in an ice bath. Then, $50 \mu \mathrm{L}$ of enzyme extracts was added. The curve of absorption changes was assessed by spectrophotometry at $425 \mathrm{~nm}$. The peroxidase enzyme activity was expressed as $\mathrm{u} / \mathrm{mg}$ protein of the sample.

\subsection{Ascorbate Peroxidase Enzyme Activity}

Ascorbate peroxidase was assayed from the decrease in absorbance at $290 \mathrm{~nm}$ as ascorbate was oxidized [59]. The samples were powdered in liquid nitrogen, and the enzymatic extract was extracted in $\mathrm{Na}_{2} \mathrm{HPO}_{4} / \mathrm{KH}_{2} \mathrm{PO}_{4}$ buffer at $50 \mathrm{mM}$ and $\mathrm{pH}=7$. The extract was centrifuged at $10,000 \times g$ for $10 \mathrm{~min}$. For the measurement of enzyme activity: $300 \mu \mathrm{L}$ 
of sodium phosphate buffer ( $\mathrm{pH}=7$, containing 0.2 EDTA mM), $200 \mu \mathrm{L}$ of ascorbic acid $(0.5 \mathrm{mM}), 200 \mu \mathrm{L}$ of Bovine Serum Albumin (BSA), $50 \mu \mathrm{L}$ of enzyme extract, and $50 \mu \mathrm{L}$ of hydrogen peroxide $(250 \mathrm{mM})$ were mixed. Absorption changes were measured by spectrophotometry at $290 \mathrm{~nm}$ for $3 \mathrm{~min}$. The enzyme activity was calculated using the extinction coefficient of ascorbic acid $\left(\mathrm{mM}^{-1} \mathrm{~cm}^{-1}\right)$ according to unit/mg protein of the sample.

\subsection{Statistical Analysis}

This experiment was carried out based on a completely randomized design with 4 (concentrations of essential oils) $\times 4$ (storage times) $\times 4$ replications (each replication included $60 \mathrm{~g}$ fruits). One-way ANOVA was used for analyzing the data (SAS, version 9.1.3, SAS Institute Inc., Cary, NC, USA). The means of scores were compared using Duncan's Multiple Range Test. Differences at $p<0.01$ were considered significant.

\section{Conclusions}

The aim of the present work was to extend the shelf life of strawberries by using nonchemical post-harvest treatment. Treated strawberries with Aloysia citrodora EOs had less weight loss and higher biochemical contents, antioxidant properties, and enzyme activity compared to control. According to obtained results, the Aloysia citrodora EOs (particularly 500-750 ppm) could potentially improve shelf life, safety, and biochemical components retention by decreasing the decay rate in strawberries in cold storage. The outcomes of the present work provide new safe and Gras additives to the production of new products for the post-harvest and food industries, but further research is needed to obtain more details on Aloysia citrodora EOs.

Author Contributions: Conceptualization, H.S. and A.A.; writing—original draft preparation, H.S. and B.G.; writing-review and editing, H.S., A.A., K.A., M.Y., B.G., M.P., and J.M.L. All authors have read and agreed to the published version of the manuscript.

Funding: This research received no external funding.

Institutional Review Board Statement: Not applicable.

Informed Consent Statement: Not applicable.

Data Availability Statement: The data presented in this study are available on request from the corresponding authors. The data are not publicly available due to being part of a research project.

Acknowledgments: Authors would like to acknowledge Urmia University (Urmia, Iran) for supporting this research.

Conflicts of Interest: The authors declare no conflict of interest.

\section{References}

1. Kafkas, E.; Koşar, M.; Paydaş, S.; Kafkas, S.; Başer, K.H.C. Quality characteristics of strawberry genotypes at different maturation stages. Food Chem. 2007, 100, 1229-1236. [CrossRef]

2. Battino, M.; Giampieri, F.; Cianciosi, D.; Ansary, J.; Chen, X.; Zhang, D.; Gil, E.; Forbes-Hernández, T. The roles of strawberry and honey phytochemicals on human health: A possible clue on the molecular mechanisms involved in the prevention of oxidative stress and inflammation. Phytomedicine 2020. [CrossRef] [PubMed]

3. Khripach, V.; Zhabinskii, V.; De Groot, A. Twenty years of brassinosteroids: Steroidal plant hormones warrant better crops for the XXI century. Ann. Bot. 2000, 86, 441-447. [CrossRef]

4. Alirezalu, A.; Ahmadi, N.; Salehi, P.; Sonboli, A.; Alirezalu, K.; Mousavi Khaneghah, A.; Barba, F.J.; Munekata, P.E.S.; Lorenzo, J.M. Physicochemical Characterization, Antioxidant Activity, and Phenolic Compounds of Hawthorn (Crataegus spp.) Fruits Species for Potential Use in Food Applications. Foods 2020, 9, 436. [CrossRef] [PubMed]

5. Ishkeh, S.R.; Shirzad, H.; Asghari, M.R.; Alirezalu, A.; Pateiro, M.; Lorenzo, J.M. Effect of Chitosan Nanoemulsion on Enhancing the Phytochemical Contents, Health-Promoting Components, and Shelf Life of Raspberry (Rubus sanctus Schreber). Appl. Sci. 2021, 11, 2224. [CrossRef]

6. Chu, Y.; Gao, C.C.; Liu, X.; Zhang, N.; Xu, T.; Feng, X.; Yang, Y.; Shen, X.; Tang, X. Improvement of storage quality of strawberries by pullulan coatings incorporated with cinnamon essential oil nanoemulsion. LWT 2020, 122, 109054. [CrossRef]

7. Mo, E.K.; Sung, C.K. Phenylethyl alcohol (PEA) application slows fungal growth and maintains aroma in strawberry. Postharvest Biol. Technol. 2007, 45, 234-239. [CrossRef] 
8. Inselberg, H.; do Nascimento Nunes, M.C. Using Cannabidiol as a potential postharvest treatment to maintain quality and extend the shelf life of strawberries. Postharvest Biol. Technol. 2021, 173, 111416. [CrossRef]

9. Alirezalu, K.; Pateiro, M.; Yaghoubi, M.; Alirezalu, A.; Peighambardoust, S.H.; Lorenzo, J.M. Phytochemical constituents, advanced extraction technologies and techno-functional properties of selected Mediterranean plants for use in meat products. A comprehensive review. Trends Food Sci. Technol. 2020, 100, 292-306. [CrossRef]

10. Alirezalu, K.; Pirouzi, S.; Yaghoubi, M.; Karimi-Dehkordi, M.; Jafarzadehe, S.H.; Mousavi Khaneghah, A. Packaging of beef fillet with active chitosan film incorporated with $\varepsilon$-polylysine: An assessment of quality indices and shelf life. Meat Sci. 2021, 176, 108475. [CrossRef]

11. Yaghoubi, M.; Ayaseh, A.; Alirezalu, K.; Nemati, Z.; Pateiro, M.; Lorenzo, J.M. Effect of Chitosan Coating Incorporated with Artemisia fragrans Essential Oil on Fresh Chicken Meat during Refrigerated Storage. Polymers 2021, 13, 716. [CrossRef]

12. Aloui, H.; Khwaldia, K.; Licciardello, F.; Mazzaglia, A.; Muratore, G.; Hamdi, M.; Restuccia, C. Efficacy of the combined application of chitosan and Locust Bean Gum with different citrus essential oils to control postharvest spoilage caused by Aspergillus flavus in dates. Int. J. Food Microbiol. 2014, 170, 21-28. [CrossRef]

13. Bill, M.; Sivakumar, D.; Korsten, L.; Thompson, A.K. The efficacy of combined application of edible coatings and thyme oil in inducing resistance components in avocado (Persea americana Mill.) against anthracnose during post-harvest storage. Crop Prot. 2014, 64, 159-167. [CrossRef]

14. Kim, N.-S.; Lee, D.-S. Headspace solid-phase microextraction for characterization of fragrances of lemon verbena (Aloysia triphylla) by gas chromatography-mass spectrometry. J. Sep. Sci. 2004, 27, 96-100. [CrossRef] [PubMed]

15. Quirantes-Piné, R.; Herranz-López, M.; Funes, L.; Borrás-Linares, I.; Micol, V.; Segura-Carretero, A.; Fernández-Gutiérrez, A. Phenylpropanoids and their metabolites are the major compounds responsible for blood-cell protection against oxidative stress after administration of Lippia citriodora in rats. Phytomedicine 2013, 20, 1112-1118. [CrossRef] [PubMed]

16. Portmann, E.; Nigro, M.M.L.; Reides, C.G.; Llesuy, S.; Ricco, R.A.; Wagner, M.L.; Gurni, A.A.; Carballo, M.A. Aqueous extracts of Lippia turbinata and Aloysia citriodora (Verbenaceae): Assessment of antioxidant capacity and DNA damage. Int. J. Toxicol. 2012, 31, 192-202. [CrossRef]

17. Temkin-Gorodeiski, N.; Shapiro, B.; Grinberg, S.; Rosenberger, I.; Fallik, E. Post harvest treatments to control eggplant deterioration during storage. J. Hortic. Sci. 1993, 68, 689-693. [CrossRef]

18. Fallik, E.; Grinberg, S.; Alkalai, S.; Yekutieli, O.; Wiseblum, A.; Regev, R.; Beres, H.; Bar-Lev, E. A unique rapid hot water treatment to improve storage quality of sweet pepper. Postharvest Biol. Technol. 1999, 15, 25-32. [CrossRef]

19. Klein, I.; Strime, M.; Fanberstein, L.; Mani, Y. Irrigation and fertigation effects on phosphorus and potassium nutrition of wine grapes. Vitis 2000, 39, 55-62. [CrossRef]

20. Shojaie, B.; Mostajeran, A.; Ghanadian, M. Flavonoid dynamic responses to different drought conditions: Amount, type, and localization of flavonols in roots and shoots of Arabidopsis thaliana L. Turkish J. Biol. 2016, 40, 612-622. [CrossRef]

21. Vargas, M.; Albors, A.; Chiralt, A.; González-Martínez, C. Quality of cold-stored strawberries as affected by chitosan-oleic acid edible coatings. Postharvest Biol. Technol. 2006, 41, 164-171. [CrossRef]

22. Gao, P.; Zhu, Z.; Zhang, P. Effects of chitosan-glucose complex coating on postharvest quality and shelf life of table grapes. Carbohydr. Polym. 2013, 95, 371-378. [CrossRef]

23. Amal, S.H.A.; El-Mogy, M.M.; Aboul-Anean, H.E.; Alsanius, B.W. Improving strawberry fruit storability by edible coating as a carrier of thymol or calcium chloride. J. Hortic. Sci. Ornam. Plants 2010, 2, 88-97.

24. Baldwin, E.A.; Nisperos-Carriedo, M.O.; Baker, R.A. Use of Edible Coatings to Preserve Quality of Lightly (and Slightly) Processed Products. Crit. Rev. Food Sci. Nutr. 1995, 35, 509-524. [CrossRef] [PubMed]

25. Sha, S.F.; Li, J.C.; Zhang, S.L. Change in the organic acid content and releted metabolic enzyme activities in developing Xinping pear fruit. Afr. J. Agric. Res. 2011, 6, 3560-3566. [CrossRef]

26. Burdurlu, H.S.; Koca, N.; Karadeniz, F. Degradation of vitamin C in citrus juice concentrates during storage. J. Food Eng. 2006, 74, 211-216. [CrossRef]

27. HongBo, S.; ZongSuo, L.; MingAn, S.; ShiMeng, S.; ZanMin, H. Investigation on dynamic changes of photosynthetic characteristics of 10 wheat (Triticum aestivum L.) genotypes during two vegetative-growth stages at water deficits. Colloids Surfaces B Biointerfaces 2005, 43, 221-227. [CrossRef]

28. Neri, F.; Mari, M.; Brigati, S.; Bertolini, P. Fungicidal activity of plant volatile compounds for controlling Monilinia laxa in stone fruit. Plant Dis. 2007, 91, 30-35. [CrossRef]

29. Serrano, M.; Martinez-Romero, D.; Castillo, S.; Guille, F.; Valero, D. The use of natural antifungal compounds improves the beneficial effect of MAP in sweet cherry storage. Innov. Food Sci. Emerg. Technol. 2005, 6, 115-123. [CrossRef]

30. Prasad, K.; Stadelbacher, G.J. Effect of acetaldehyde vapor on postharvest decay and market quality of fresh strawberries. Phytopathology 1974, 64, 948-951. [CrossRef]

31. Alirezalu, K.; Shafaghi Molan, H.; Yaghoubi, M.; Pateiro, P.; Lorenzo, J.M. $\varepsilon$-polylysine coating with stinging nettle extract for fresh beef preservation. Meat Sci. 2021, 176, 108474. [CrossRef] [PubMed]

32. Alirezalu, K.; Hesari, J.; Yaghoubi, M.; Mousavi Khaneghah, A.; Alirezalu, A.; Pateiro, M.; Lorenzo, J.M. Combined effects of $\varepsilon$-polylysine and $\varepsilon$-polylysine nanoparticles with plant extracts on the shelf life and quality characteristics of nitrite-free frankfurter-type sausages. Meat Sci. 2021, 172, 108318. [CrossRef] 
33. Alirezalu, K.; Yaghoubi, M.; Nemati, Z.; Farmani, B.; Mousavi Khaneghah, A. Efficacy of stinging nettle extract in combination with $\varepsilon$-polylysine on the quality, safety, and shelf life of rainbow trout fillets. Food Sci. Nutr. 2021. [CrossRef]

34. Alirezalu, A.; Salehi, P.; Ahmadi, N.; Sonboli, A.; Aceto, S.; Hatami Maleki, H.; Ayyari, M. Flavonoids profile and antioxidant activity in flowers and leaves of hawthorn species (Crataegus spp.) from different regions of Iran. Int. J. Food Prop. 2018, 21, 452-470. [CrossRef]

35. Shameh, S.; Alirezalu, A.; Hosseini, B.; Maleki, R. Fruit phytochemical composition and color parameters of 21 accessions of five Rosa species grown in North West Iran. J. Sci. Food Agric. 2019, 99, 5740-5751. [CrossRef] [PubMed]

36. Synowiec, A.; Gniewosz, M.; Kraśniewska, K.; Przybył, J.L.; Bączek, K.; Wȩglarz, Z. Antimicrobial and antioxidant properties of pullulan film containing sweet basil extract and an evaluation of coating effectiveness in the prolongation of the shelf life of apples stored in refrigeration conditions. Innov. Food Sci. Emerg. Technol. 2014, 23, 171-181. [CrossRef]

37. Sellamuthu, P.S.; Sivakumar, D.; Soundy, P.; Korsten, L. Essential oil vapours suppress the development of anthracnose and enhance defence related and antioxidant enzyme activities in avocado fruit. Postharvest Biol. Technol. 2013, 81, 66-72. [CrossRef]

38. Hussain, P.R.; Suradkar, P.P.; Wani, A.M.; Dar, M.A. Potential of carboxymethyl cellulose and $\gamma$-irradiation to maintain quality and control disease of peach fruit. Int. J. Biol. Macromol. 2016, 82, 114-126. [CrossRef] [PubMed]

39. Lorenzo, J.M.; Pateiro, M.; Domínguez, R.; Barba, F.J.; Putnik, P.; Kovačević, D.B.; Shpigelman, A.; Granato, D.; Franco, D. Berries extracts as natural antioxidants in meat products: A review. Food Res. Int. 2018, 106, 1095-1104. [CrossRef] [PubMed]

40. Gang, W.; Zhen-Kuan, W.; Yong-Xiang, W.; Li-Ye, C.; Hong-Bo, S. The mutual responses of higher plants to environment: Physiological and microbiological aspects. Colloids Surfaces B Biointerfaces 2007, 59, 113-119. [CrossRef]

41. Dris, R.; Niskanen, R.; Jain, S.M. Crop Management and Postharvest Handling of Horticultural Products; Science Publishers: Enfield, UK, 2001.

42. Yang, G.; Yue, J.; Gong, X.; Qian, B.; Wang, H.; Deng, Y.; Zhao, Y. Blueberry leaf extracts incorporated chitosan coatings for preserving postharvest quality of fresh blueberries. Postharvest Biol. Technol. 2014, 92, 46-53. [CrossRef]

43. Wang, W.D.; Xu, S.Y. Degradation kinetics of anthocyanins in blackberry juice and concentrate. J. Food Eng. 2007, 82, 271-275. [CrossRef]

44. Singh, R.; Rastogi, S.; Dwivedi, U.N. Phenylpropanoid metabolism in ripening fruits. Compr. Rev. Food Sci. Food Saf. 2010, 9 , 398-416. [CrossRef]

45. Pourmorad, F.; Hosseini Mehr, S.J.; Shahabimajd, N. Antioxidant activity, phenol and flavonoid contents of some selected Iranian medicinal plants. Afr. J. Biotechnol. 2006, 5, 1142-1145.

46. Tripathi, P.; Dubey, N.K.; Banerji, R.; Chansouria, J.P.N. Evaluation of some essential oils as botanical fungitoxicants in management of post-harvest rotting of citrus fruits. World J. Microbiol. Biotechnol. 2004, 20, 317-321. [CrossRef]

47. Da Silva, F.L.; Escribano-Bailón, M.T.; Pérez Alonso, J.J.; Rivas-Gonzalo, J.C.; Santos-Buelga, C. Anthocyanin pigments in strawberry. LWT Food Sci. Technol. 2007, 40, 374-382. [CrossRef]

48. Bartosz, G. Oxidative stress in plants. Acta Physiol. Plant 1997, 19, 47-64. [CrossRef]

49. Jaleel, C.A.; Manivannan, P.; Wahid, A.; Farooq, M.; Al-Juburi, H.J.; Somasundaram, R.; Panneersel-Vam, R. Drought stress in plants: A review on morphological characteristics and pigments composition. Int. J. Agric. Biol. 2009, 11, $100-105$.

50. Afshar Mohammadian, M.; Rezaei, S.H.; Ramezani, M.R. Investigation of the resistance of two olive cultivars to cold stress. J. Process Plant Funct. 2012, 2, 1-11.

51. Hernández-Muñoz, P.; Almenar, E.; Del Valle, V.; Velez, D.; Gavara, R. Effect of chitosan coating combined with postharvest calcium treatment on strawberry (Fragaria $\times$ ananassa) quality during refrigerated storage. Food Chem. 2008, 110, 428-435. [CrossRef]

52. Khosroshahi, M.R.Z.; Esna-Ashari, M.; Ershadi, A. Effect of exogenous putrescine on post-harvest life of strawberry (Fragaria ananassa Duch.) fruit, cultivar Selva. Sci. Hortic. 2007, 114, 27-32. [CrossRef]

53. Ayala-Zavala, J.F.; Wang, S.Y.; Wang, C.Y.; González-Aguilar, G.A. High oxygen treatment increases antioxidant capacity and postharvest life of strawberry fruit. Food Technol. Biotechnol. 2007, 45, 166-173.

54. Moshari-Nasirkandi, A.; Alirezalu, A.; Hachesu, M.A. Effect of lemon verbena bio-extract on phytochemical and antioxidant capacity of strawberry (Fragaria $\times$ ananassa Duch. cv. Sabrina) fruit during cold storage. Biocatal. Agric. Biotechnol. 2020, 25, 101613. [CrossRef]

55. Schieber, A.; Keller, P.; Carle, R. Determination of phenolic acids and flavonoids of apple and pear by high-performance liquid chromatography. J. Chromatogr. 2001, 910, 265-273. [CrossRef]

56. Navarro, J.M.; Flores, P.; Garrido, C.; Martinez, V. Changes in the contents of antioxidant compounds in pepper fruits at different ripening stages, as affected by salinity. Food Chem. 2006, 96, 66-73. [CrossRef]

57. Shin, Y.; Liu, R.H.; Nock, J.F.; Holliday, D.; Watkins, C.B. Temperature and relative humidity effects on quality, total ascorbic acid, phenolics and flavonoid concentrations, and antioxidant activity of strawberry. Postharvest Biol. Technol. 2007, 45, 349-357. [CrossRef]

58. Mohammadi, A.; Hashemi, M.; Hosseini, S.M. Chitosan nanoparticles loaded with Cinnamomum zeylanicum essential oil enhance the shelf life of cucumber during cold storage. Postharvest Biol. Technol. 2015, 110, 203-213. [CrossRef]

59. Nakano, Y.; Asada, K. Hydrogen Peroxide is Scavenged by Ascorbate-specific Peroxidase in Spinach Chloroplasts. Plant Cell Physiol. 1981, 22, 867-880. [CrossRef] 